\title{
IMPRESSION MANAGEMENT STRATEGY OF COPING WITH ENTREPRENEURIAL FAILURE STIGMA: A TWO-PATH THEORETICAL MODEL
}

\section{Zhuang Xiong', Junzhou Yan², Lingling Wang ${ }^{3}$}

1 Zhengzhou University of Aeronautics, School of Business, Department of Marketing, China, ORCID: 0000-00024586-4561, xiongzhuang@zua.edu.cn;

2 Zhengzhou University of Aeronautics, School of Business, Department of Business Administration, China, ORCID: 0000-0003-4393-9483, yjz1688@sina.com (corresponding author);

3 Zhengzhou University of Aeronautics, School of Business, Department of Business Administration, China, ORCID: 0000-0002-3172-7195, ling_1272@163.com.

\begin{abstract}
Impression management strategy is an important way to cope with the stigma of failed entrepreneurial firms. However, most existing studies only focused on the process of impression management with a single strategy. Few studies have provided a systematic theoretical explanation on how to use different types of impression management strategies to cope with stigma. To fill this theoretical gap, a two-path model of impression management of entrepreneurial failure stigma was constructed, based on the two-component model of impression management. In addition, the mechanism of impression management strategy selection for failed entrepreneurial firms to cope with stigma was discussed. The findings of the theoretical model reveal two paths for the stigma management strategy of failed entrepreneurial firms: "avoidance motivation $\rightarrow$ defensive strategy of impression management" and "diluted motivation $\rightarrow$ acquisitive strategy of impression management." Moreover, in the selection mechanism of strategy, the formation of impression motivation is affected by the stigma type of entrepreneurial failure, the social status of the firm organization, and the degree of stigma threat. In the face of justifiable stigma, the failed entrepreneurial firms form the avoidance motivation and then implement a defensive strategy of impression management. High social status firms adopt an acquisitive strategy of impression management to cope with the negative impact of entrepreneurial failure stigma. As the threat level of entrepreneurial failure stigma increases, the dilution motivation of the failed entrepreneurial firms to stigma becomes stronger, and the firms are more likely to adopt the acquisitive strategy of impression management. The two-path theoretical model provides decision support for failed entrepreneurial firms to formulate stigma management strategies and expands the research scope of entrepreneurial failure stigma.
\end{abstract}

Keywords: Entrepreneurial failure stigma, impression management strategy, two-path theoretical model.

JEL Classification: M13, 031, 035.

APA Style Citation: Xiong, Z., Yan, J., \& Wang, L. (2021). Impression Management Strategy of Coping with Entrepreneurial Failure Stigma: A Two-path Theoretical Model. E\&M Economics and Management, 24(4), 72-85. https://doi.org/10.15240/tul/001/2021-4-005

\section{Introduction}

In recent years, despite the slowdown in the world economic performance, the trend of world innovation is still booming. The Global
Innovation Index 2019 released by the World Intellectual Property Organization (WIPO) showed that the growth rate of global research and development expenditure is higher than 
that of global economy. As the foundation of entrepreneurship, the continuous improvement of innovation develops entrepreneurial activities. Moreover, the scale of entrepreneurial groups is expanding, and a vigorous entrepreneurial boom has formed through the implementation of positive entrepreneurial policies (Wang et al., 2019). However, the uncertainty and high risk in the entrepreneurship process determine that entrepreneurship is not smooth sailing. In particular, COVID-19 continues to spread throughout the world, and the business environment faced by new ventures is more difficult. More and more enterprises are unable to survive. The phenomenon of entrepreneurial failure exists objectively. Relevant data show that the failure rate of Chinese youth first venture is as high as $90 \%$ (Zheng et al., 2019). Furthermore, even the Chinese unicorn enterprises, such as OFO sharing bicycles, is from the favorite of the capital market to the end of brand failure.

Entrepreneurial failure brings material and emotional losses to the entrepreneurial firms and also brings significant symbolic effects on the failed entrepreneurial firm (Yannopoulou et al., 2011). In particular, China's traditional cultural thought of winner-take-all has gradually led to the stigmatization of failed entrepreneurial firms by the public (Zhang et al., 2013). Failed entrepreneurial firms are given negative labels of failure, incompetence, and defect by the public ( $\mathrm{Li}$ et al., 2019). For example, the failures of Bingxin Wu's Sanzhu Group, Yuzhu Shi's Giant Interactive Group, and Yueting Jia's LeEco made "infamous" after their entrepreneurial failure. Of course, the failure reflects the deficiencies of entrepreneurial factors, such as opportunities, resources, and teams. However, blindly stigmatizing the failed entrepreneurial firms will lead to preventing the re-entrepreneurship behavior of the failed entrepreneurial firms in the face of failure. Reducing entrepreneurial activities is a great loss for the whole society due to the stigma of failure. Therefore, exploring the stigma management of failed entrepreneurial firms and promoting their comeback (reentrepreneurship) have a high theoretical and practical value.

Entrepreneurial failure stigma is a new topic in the field of entrepreneurship, and related studies are still in the development stage. In addition, entrepreneurial failure stigma refers to the fact that entrepreneurs form a bad stereotype due to entrepreneurial failure and give them a derogatory label. Existing studies explored the types of stigma related to failure (Corrigan et al., 2010), formation mechanism (Li et al., 2019), and impact consequences (Zhang et al., 2021). Researchers found that failure stigma will have a very serious negative impact on the stigma recipients, which will lead to media exaggeration and severe public criticism (Simmons et al., 2019). Faced with failure stigma, failed entrepreneurial firms will take a series of strategies to repair their reputation and image (Yang et al., 2010; Lu et al., 2019). As a strategic means to maintain or repair the reputation and image of failed entrepreneurial firms, the importance of impression management in the process of coping with stigma has been concerned by theory and practice (Kibler et al., 2021). For the failed entrepreneurial firms, creating a good public impression of coping with failure is very important, which largely determines the number of resources obtained in the follow-up entrepreneurship process.

However, existing studies on how to implement the impression management strategy to cope with the stigma of failure did not provide a clear theoretical answer but presented contradictory findings. Some experimental studies found that when failed entrepreneurial firms attribute their failure to external factors beyond their control, the public response is more positive (Kibler et al., 2017). This measure not only maintains the legitimacy of the firm but also provides resource support for its subsequent entrepreneurial behavior, which is conducive to the re-entrepreneurial behavior from failure. Meanwhile, other studies showed that the implementation of impression management strategy to reduce the responsibility of entrepreneurial failure will make the public have a more negative image perception of the failed entrepreneurial firms (Cardon et al., 2011), further leading to the loss of legitimacy (Smith \& Rhiney, 2020) and inhibiting the re-entrepreneurship. How to use different types of impression management strategies to cope with the stigma of failure needs further theoretical exploration.

To fill this theoretical gap, this study focuses on the impression management of the entrepreneurial failure stigma. Based on the twocomponent model of impression management 
proposed by Leary and Kowalski (1990), a twopath model of impression management of the entrepreneurial failure stigma was constructed. Moreover, the characteristics and types of impression management strategies after entrepreneurial failure were analyzed. Then, the choice mechanism of impression management strategies in response to the stigma of failed entrepreneurial firms was discussed, aiming to provide decision support for the formulation of stigma management strategies of failed entrepreneurial firms.

The theoretical contributions of this study are as follows: the two-path theoretical model of impression management of entrepreneurial failure stigma proposed in this study is based on the two-component model of impression management. According to the discrete process of "impression motivation $\rightarrow$ impression construction," the two-path theoretical model of coping with entrepreneurial failure stigma of impression management was constructed. The two paths for the stigma management strategy of failed entrepreneurial firms are the following: "avoidance motivation $\rightarrow$ defensive strategy of impression management" and "diluted motivation $\rightarrow$ acquisitive strategy of impression management". The theoretical model provides a theoretical framework on how to manage entrepreneurial failure stigma and take targeted impression management strategies to cope with stigma. In addition, this study defines under what impression motivation the different types of entrepreneurial failure stigma impression management strategies are formed, and under what stimulating conditions the different types of impression motivation are generated. Although the two-path model proposed in this study is only primarily theoretical, this model sets the stage for empirical research and further theoretical development, expands the research ideas of entrepreneurial failure stigma management, and enriches the related research of stigma management.

\section{Literature Review}

\subsection{Entrepreneurial Failure Stigma}

Considering that the concept of stigma was redefined and put forward, relevant scholars have gradually distinguished different types of stigma, including mental illness, sexual orientation, infectious disease, sexual, racial, and obesity. Detailed studies on different types of stigma reflect the characteristics of stigma.
That is to say, when an individual's defects or mistakes in physical characteristics, behavior types, and groups violate the requirements of social norms, he/she will be disgusted, avoided, and rejected by the mainstream groups. These belittled attributes or traits also lead to the selfbelittling psychology of those who bear the stigma.

With the deepening of the understanding of stigma in the theoretical and practical fields, the discussion of stigma is not limited to the individual level. Sutton and Callahan (1987) introduced the concept of stigma into the organizational context for the first time and discussed the stigmatization process of firms facing bankruptcy. An organizational stigma is an extension of the individual stigma concept. Combined with the theory of social psychology and the labeling theory, the organizational stigma is a negative evaluation of organizations by society (Zhang et al., 2013). This kind of negative evaluation comes from the judgment and cognition of the stakeholder groups on the organizational values or norms. That is, when the organizational behavior is improper and beyond certain values or norms, generating an organizational stigma will be easy. The types of organizational stigma include event and core stigma (Schnackenberg et al., 2019). Among them, the core stigma is the original sin of some organizations, which is rooted in the social evaluation between organizational and social public values. The core stigma is also an organizational label that is extremely difficult to get rid of.

Since the beginning of the 21st century, entrepreneurial failure has become one of the hot topics in entrepreneurial research. However, the academic community has not yet formed a unified view on the definition of entrepreneurial failure (Amankwah-Amoah et al., 2015). Considering the results and reasons for the entrepreneurial failure, this study refers to the findings of Zhang et al. (2019) and Zheng et al. (2019). Entrepreneurial failure is that entrepreneurs cannot mobilize the necessary expertise and resources to cope with the old and emerging threats. Thus, firms cannot make profits or fall into financial difficulties, eventually causing entrepreneurs to terminate or withdraw from new ventures.

With the development of studies on entrepreneurial failure, scholars in the field of entrepreneurship management have begun 
to pay attention to the stigma caused by entrepreneurial failure. The entrepreneurial failure stigma refers to the negative stereotype of entrepreneurs caused by entrepreneurial failure (Li et al., 2019). Compared with the concept dimension of organizational stigma, the entrepreneurial failure stigma belongs to the category of event stigma in an organizational stigma. Entrepreneurial firms leave a negative stereotype in the public and are constantly identified and strengthened in social interaction due to entrepreneurial failure, gradually forming a stigma. Therefore, the entrepreneurial failure stigma is a type of event stigma in an organizational stigma.

The academic community has carried out exploratory research on the entrepreneurial failure stigma, focusing on the formation mechanism, the impact, and the cope with entrepreneurial failure stigma. In terms of the formation mechanism of entrepreneurial failure stigma, the label theory holds that the formation of failure stigma is a process of stigmatization from public stigma to self-identity. Once the failed entrepreneurs are labeled negatively, they will be gradually isolated by society, resulting in the loss of material resources and social status. The continuous strengthening of social discrimination further leads to the increasing self-blame and self-devaluation of stigma bearers in the formation of public stigma. This process is often influenced by social and cultural factors (Singh et al., 2015). According to attribution theory, the external attribution of entrepreneurial failure and loose public policy can reduce failure stigma (Shepherd \& Patzelt, 2015).

In terms of the impact of entrepreneurial failure stigma, the impact of failure stigma on entrepreneurs is mostly negative. At the individual level, the entrepreneurial failure stigma not only brings economic losses to entrepreneurs but also damages their physical and mental health (Singh et al., 2015), which is more likely to affect their career choices. That is, the supervision degree of institutional environment on the visibility of the stigma label will affect the future career decisionmaking of entrepreneurs and losers (Simmons et al., 2014). At the organizational level, once entrepreneurial failure stigma is formed, the organization will be labeled as untrusted and flawed by stakeholders (Li et al., 2019), which will affect the recognition of stakeholders on the organization. Moreover, obtaining resource support from the audience is difficult. At the social level, the widespread emergence of entrepreneurial failure stigma reflects the lack of social fault tolerance mechanism and then affects the public's willingness to entrepreneurship.

In the cope with failure stigma, entrepreneurs will adopt certain stigma coping strategies to reduce the negative impact of failure stigma (Yu \& Chen, 2019). In particular, as a means of maintaining or repairing reputation after organizational failure events, relevant studies emphasized the importance of impression management in the process of coping with failure stigma (Shepherd \& Haynie, 2011). Firms can design and implement certain strategies to create a pleasant self-image to curb the negative impact of stigma on their reputation or image. Bolino et al. (2016) found that when an organization experiences entrepreneurial failure, it can defensively apply the impression management strategy to restore its legitimacy and regain the legitimacy recognition of the stakeholders. Some studies also found that the effect of impression management on the reputation or image of an organization does not meet expectations after the failure event but will further aggravate the negative impact of failure stigma on the organization (Cardon et al., 2011). However, the existing literature does not provide a definite theoretical answer to this contradiction. Therefore, when entrepreneurial failure stigma occurs, how entrepreneurial failure firms adopt different impression management strategies should be clarified to cope with entrepreneurial failure stigma, to make the public and stakeholders maintain a good impression on them.

\subsection{Impression Management Strategy}

Impression management originates from Machiavellianism. The two-component model of impression management of Leary and Kowalski (1990) is the most representative. In the two-component model, impression management includes two discrete processes, namely, impression motivation and impression construction. Among them, impression motivation refers to the desire of individuals to control others' perception and impression of themselves. Impression construction is an individual meeting the impression motivation, to change their behavior to influence others' 
impression of themselves, which is the implementation strategy of producing a specific impression. With the continuous expansion of the research field of impression management, impression management at the organizational level is increasingly concerned with theory and practice. Firms design the organization pertinently, which affects the public perception response to them and thus realizes the mutual influence between the firms and the public (Elsbach \& Sutton, 1992; Martín-de Castro et al., 2020).

At the firm level, the impression management strategy refers to the method by which the firm consciously or unconsciously controls the audience's impression of the firm itself through verbal, non-verbal, and other forms, which is also a specific form of impression management. In the existing studies, impression management can be divided into two types, that is, acquisition and defensive strategies. The former refers to a firm's initiative to influence others' perception of its image, such as flattering, showing firm achievements, showing weakness, and connecting with authoritative organizations. The level effect of strategy implementation also has differences. For example, to leave a 'good impression' on the audience, executives often use consensus to please the audience (Ucbasaran et al., 2013), or through selfimprovement, personal demonstration (Nagy et al., 2012), and symbolic action to show their characteristics and talents (Zott \& Huy, 2007). To influence other people's perception of the firm's overall image, the firm will actively show its achievements, convey its achievements and areas of expertise to the stakeholders, and indicate its future potential, to strengthen the positive image perception of the firm in the stakeholders. In addition, Petkova et al. (2013) and Zott and Huy (2007) found that firms actively connect with stakeholders, industry associations, and other authoritative individuals or organizations, which is also a commonly used acquisition strategy to enhance the firm image.

Then, the defensive strategy more reflects the negative and passive impression management strategy of firms, such as silence, shirking responsibility, defending, and looking for scapegoats. The implementation of this kind of impression management strategy is mostly based on the situation of negative events, that is, the coping strategies adopted by firms or executives to avoid image damage after the occurrence of negative events (Cusin \& Passebois-Ducros, 2020). For example, Siomkos and Kurzbard (1994) pointed out that to cope with negative events, firms adopt a denial strategy to emphasize that they have nothing to do with negative events. Hampel and Tracey (2017) proposed the strategies of information cover-up, lying, and reducing the work related to negative events. The essence of these strategies is to cover up the relationship between negative events and firms, allowing the audience away from the truth of negative events. Evidently, the defensive strategy in impression management of executives or employees to cope with negative events is mostly based on the denial strategy of denying the occurrence of negative events or indicating that the firm has no relationship with the negative events, including changing the responsibility of negative events, trying to reduce the negative impact on stakeholders (Coombs, 2007). In addition, when a wide range of negative events occur in an industry, withdrawing capital from the industry and keeping away from the stigmatization industry are reasonable impression management strategies for firms (Durand \& Vergne, 2015). Moreover, when a firm increases its short-term profits through speculative behavior if such behavior is contrary to the values or ethics of stakeholders, the firm also takes advantage of the information asymmetry between the firm and the public to claim that this type of behavior has not occurred, or look for scapegoats responsible for this type of behavior (Yang \& Guo, 2017).

The impression management strategy has high applicability to solve the problem of how to obtain and maintain the legitimacy of new ventures when facing the liabilities of newness (Yu \& Chen, 2019). On the one hand, compared with mature firms, the vulnerability and risk resistance of entrepreneurial firms are weaker, and they are more vulnerable to the negative impact of negative events. Through the implementation of the impression management strategy, entrepreneurial firms can effectively reduce the threat of negative events to entrepreneurial legitimacy (Kibler et al., 2017). On the other hand, the products and services of entrepreneurial firms in the start-up period bring direct impression perception to the public. Moreover, the impression management 
of products and services can send an important signal of good reputation of entrepreneurial firms to stakeholders, to help them obtain additional resource support from stakeholders and reduce the liabilities of newness (Soublière \& Gehman, 2020).

The implementation effect of the impression management strategy in the entrepreneurial process is mainly based on legitimacy and signal theories. First, the legitimacy theory mainly focuses on how to obtain legitimacy through impression management for entrepreneurial firms, that is, to meet others' expectations of entrepreneurial firms by showing the identities of 'technical experts', 'social' firms, and 'entrepreneurs' to the public or stakeholders (Kibler et al., 2017). Through their social networks to form a connection mechanism with authoritative organizations (Zott \& Huy, 2007), or through the release of milestone news to obtain industry media and investor recognition (Petkova et al., 2013), obtaining the audience's recognition is easier, thus obtaining entrepreneurial legitimacy. Second, the signal theory emphasizes the use of impression management to help entrepreneurial firms obtain resources. Zott and Huy (2007) found that entrepreneurial firms can send signals of professionalism and reliability to the public by showing personal credit and past achievements, and they are more likely to obtain external resource support. Moreover, the effect of such signaling is more evident in the context of China's face culture, which can not only obtain more resource support but also more easily form strategic alliances in social networks (Stern et al., 2014; Yu \& Chen, 2019).

Furthermore, the application of the impression management strategy can effectively reduce the negative impact of entrepreneurial failure stigma (Kibler et al., 2017). Specifically, entrepreneurial firms can prove the objectivity and inevitability of entrepreneurial failure through three attribution ways and use the adjustment of entrepreneurial failure information to create a good impression in the eyes of the public. Based on the findings of Sutton and Callahan (1987), Shepherd and Haynie (2011) further clarified three impression management strategies and the combination of strategy implementation about the legitimacy maintenance of failed entrepreneurial firms. First, entrepreneurial failure was defined from a positive perspective. Acknowledging that the entrepreneurial activities have stopped, the entrepreneurial firms emphasize the positive value of failure. For example, learning from failure can improve a firm's entrepreneurial and risk assessment abilities. Failure attribution focuses on stability and shows stakeholders that entrepreneurial failure experience can ensure that failure is unlikely to happen again in the follow-up entrepreneurship process. Second, the responsibility of denying entrepreneurial failure is that entrepreneurs protect the firm's reputation by weakening their role in failure and attributing them to external reasons. This kind of failure attribution emphasizes the causal relationship and the external track of uncontrollable. Third, entrepreneurs advocate a negative selfconcept, emphasizing the commitment of entrepreneurs to entrepreneurial firms, the losses caused by failure, and the female role of entrepreneur (Lu et al., 2020), rather than taking failure as a positive experience, thus arousing the sympathy of the public (Sutton \& Callahan, 1987). This kind of failure attribution emphasizes the causal relationship and the internal track of controllability.

Evidently, the purpose of impression management of entrepreneurial failure stigma is more reflected in the maintenance of legitimacy of the failed entrepreneurial firm. That is, the implementation of impression management strategy makes entrepreneurial failure seem legitimate (Singh et al., 2015). By emphasizing some attributes, entrepreneurial firms regulate the provision of entrepreneurial failure information while weakening or even hiding other attributes (Überbacher et al., 2015), to minimize entrepreneurial failure stigma in the public and stakeholders and to restore the good impression in the eyes of previous stakeholders. Moreover, the impression management of entrepreneurial failure stigma can support entrepreneurs' emotional recovery and learning from failure (Byrne \& Shepherd, 2015) and help to establish a legal professional image in the follow-up entrepreneurial activities.

\section{Impression Management of Entrepreneurial Failure Stigma: A Two-path Model}

\subsection{Theoretical Model}

After a failure stigma event, the failed entrepreneurial firms often use the impression management strategy to reduce the negative 


\section{Business Administration and Management}

impact of stigma (Lashley \& Pollock, 2020). Referring to the two-component model of impression management proposed by Leary and Kowalski (1990), this study holds that the implementation process of impression management strategy after entrepreneurial failure is a discrete process including impression motivation and impression construction. Among them, impression motivation refers to the failed entrepreneurial firms to shape the public or stakeholders' views on their entrepreneurial failure. Impression construction refers to the types and ways of impression management strategies implemented by failed entrepreneurial firms to satisfy and realize impression motivation. The process of impression management emphasizes that impression motivation determines impression construction, that is, under the condition of clarifying the motivation to cope with the stigma, the entrepreneurial firms adopt different impression management strategies according to the different motivations.

The impression management strategy refers to the means adopted by entrepreneurs to influence others' perception of firm image. From the perspective of impression motivation in the two-component model, the differences in the expected goals of the failed entrepreneurial firms to cope with stigma also lead to different impression management motivations. Kibler et al. (2017) found that when the entrepreneurial failure stigma occurs, entrepreneurial firms will emphasize that the failure is caused by external factors, and not their ability defects, that is, by keeping a distance from the entrepreneurial failure to resist the stigma, maintain their legitimacy, try to minimize the negative impact of failure stigma, and form avoidance motivation to entrepreneurial failure stigma. In other related studies, impression management motivation is not only limited to resisting and avoiding stigma but is also to repair the negative reputation due to failure stigma by prosocial behavior, such as showing firm achievements (Petkova et al., 2013), actively participating in public welfare activities, and cooperating with government projects (Pache \& Santos, 2013). When making up for the difference between the current and the expected image, failed entrepreneurial firms try to release reliable and competitive positive signals to the outside world. The objective is to obtain legitimacy for re-entrepreneurship and form the diluted motivation to entrepreneurial failure stigma. Therefore, drawing on the theoretical framework of the two-component model of impression management, this study divides impression management motivations into two types, namely, avoidance and diluted motivation, according to the characteristics of entrepreneurial failure situation and the expected goal difference of stigma response.

Furthermore, from the notion of Leary and Kowalski (1990) that impression motivation determines impression construction; the difference of impression motivation in stigma

\section{Fig. 1: Two-path theoretical model of impression management}

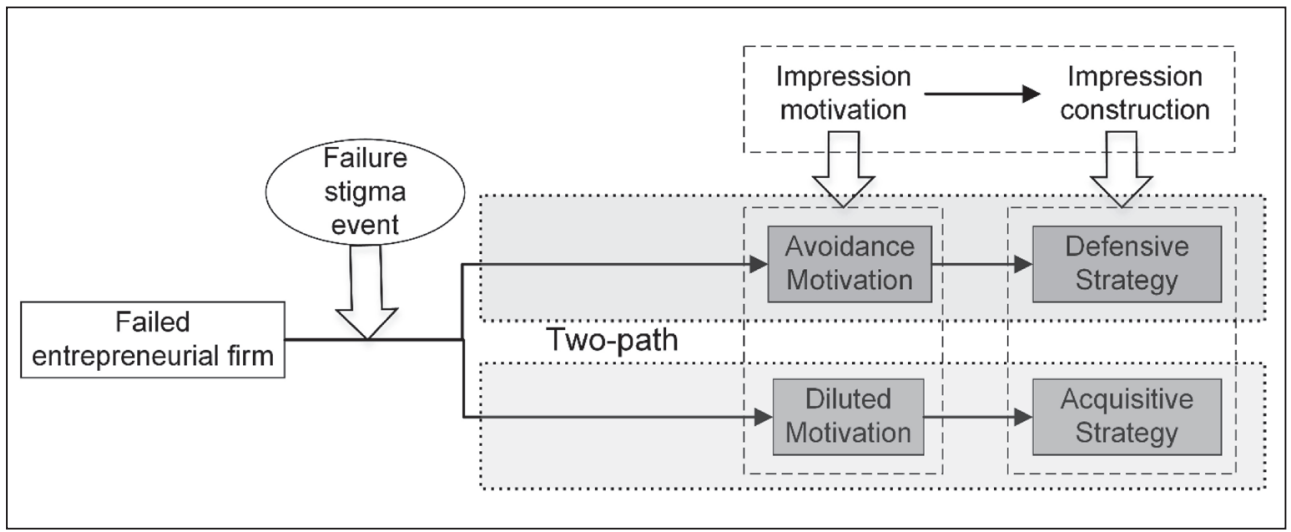


response also determines the different types of impression management strategies. In the field of impression management, the discussion on the types of impression management strategies is mainly based on two specific forms, that is, defensive (e.g., defense, shirking responsibility, silence) and acquisitive (e.g., courtship, symbolic action, showing firm achievements) strategies. The former is a negative and passive means of impression management, whereas the latter is to actively influence others' perception of their image and reputation. Evidently, according to the motivation types of implementing impression management, the formation of avoidance motivation exactly determines that the failed entrepreneurial firms take defensive strategy to resist stigma, whereas diluted motivation promotes the failed entrepreneurial firms to implement the acquisitive strategy for impression management.

Therefore, based on the two-component model of impression management, this study divides the motivation of coping with stigma after entrepreneurial failure into avoidance and diluted motivation. According to this classification and the findings of Bolino et al. (2008, 2016) and Yu and Chen (2019), impression management strategies are divided into defensive and acquisitive strategies. Moreover, a two-path theoretical model of impression management for entrepreneurial failure stigma was constructed (Fig. 1).

\subsection{Selection Mechanism of Impression Management Strategy}

Combined with the results of Fig. 1, according to the formation mechanism of 'impression motivation $\rightarrow$ impression construction' (Leary \& Kowalski, 1990), when firms are stimulated by failure stigma events in the entrepreneurial process, they will produce two different impression motivations (avoidance and diluted motivations). In addition, different impression motivations have a different impression construction strategy, which leads to two ways of impression management strategies for coping with entrepreneurial failure stigma: 'avoidance motivation $\rightarrow$ defensive strategy' and 'diluted motivation $\rightarrow$ acquisitive strategy'. Furthermore, how does the differentiated impression motivation form? How does impression motivation feedback the selection of impression management strategy of failed entrepreneurial firms? The selection mechanism of different types of impression management strategies needs to be explored.

According to the two-component model of impression management of Leary and Kowalski (1990), the main factors influencing impression motivation include three aspects: (1) the degree of correlation between the organization and the object of impression management; (2) the gap between the expected image and the current organization image; (3) the organization's image of publicity. When the failed entrepreneurial firms detect the stimulation of failure stigma on their reputation image, they will have the consciousness of controlling the negative impact of failure stigma, thereby forming the impression motivation. Furthermore, under the intervention of the above factors, the impression motivation intensity of the entrepreneurial firms is further affected, leading to the difference in the expected objectives of the failure stigma response.

First, according to the findings of Zhang and Luo (2013) and Yang et al. (2017), when defining clearly the causes of negative events is difficult, crisis firms often have more room to explain. At this time, crisis firms can obtain stronger credibility by adopting an impression management strategy, thus producing a strong impression motivation. When the cause and responsibility of the negative events are clear, the reputation repair strategy adopted by the crisis firms often provides the impression management objects to form a suspicion of "showing off." The implementation effect of the impression management strategy is just the opposite, thus producing a poor impression motivation. Based on the classification of negative events of Zhang and Luo (2013), this study divides the types of entrepreneurial failure stigma into a justifiable and unjustifiable stigma. In the stigma event situation when the implementation object of impression management strategy has a high degree of relevance with the failed entrepreneurial firms, such as the consumers with high brand loyalty and a high degree of connection, a certain redundancy space is provided for the stigma response of the failed entrepreneurial firms. In other words, based on the previous firm cognition, the object of impression management can accept and recognize the passive justification of the failed entrepreneurial firms, to avoid stigma and reduce the negative impact of entrepreneurial failure through the 
implementation of defensive strategy. When the object of impression management is a wider audience, defensive strategy needs to be more cautious in explaining the responsibility for failure. Alittle carelessness will further aggravate the negative impression of stakeholders on the firm itself. Moreover, the failed entrepreneurial firms are not only limited to avoiding failure stigma but also expect to dilute the negative reputation and image caused by the failure through a series of active acquisitive strategies, to further enhance the stakeholders' awareness of the positive image of the firm.

Second, Turney et al. (2001) found that the high self-monitoring group experienced increasing effective use of impression management strategies than the low self-monitoring group. High social status organizations belong to high self-monitoring groups and are at the top of their relative position in the industry. Compared with their followers, they can obtain more resources from prestige and power (Bernardino \& Freitas Santos, 2019). Therefore, when the entrepreneurial failure stigma affects the social status of firms in the industry, the impression management strategy adopted by the firms to cope with stigma may also depend on their social status to maintain their previous organizational image. Specifically, as the social status of the failed entrepreneurial firms before the failure stigma increases, forming diluted motivation of the failure stigma and then implementing the acquisitive strategy of impression management will be easier. On the contrary, as the social status decreases, the failed entrepreneurial firms are more likely to form avoidance motivation of the failure stigma, to implement the defensive strategy of impression management.

Finally, the spread and diffusion of stigma events cannot be separated from the media attention. If the media attention to stigma events is high, then the organization's image of publicity is strong (McDonnell \& King, 2013). If the media pay attention to the failed entrepreneurial firms, then, to pursue sensational effect, the media will legalize entrepreneurial failure stigma recessively in the process of information dissemination, or attract the attention of the public through eyecatching headlines (Xiong et al., 2011). Therefore, the election of impression management strategy of failed entrepreneurial firms to cope with stigma is likely to depend on the media range that failure stigma can affect. As the media pay more attention to entrepreneurial failure stigma, firms will highly think that the threat of entrepreneurial failure stigma to their reputation and image is greater, and the diluted motivation of the stigma is stronger, to take the acquisitive strategy of impression management to neutralize the stigma attacks of the media. If the media's attention to entrepreneurial failure stigma is relatively limited, then the firms' avoidance motivation of the failure stigma is stronger, so they can implement a defensive strategy of impression management to resist the stigma.

Fig. 2 depicts the selection mechanism of impression management strategy to cope with

\section{Fig. 2: Selection mechanism of impression management strategy}

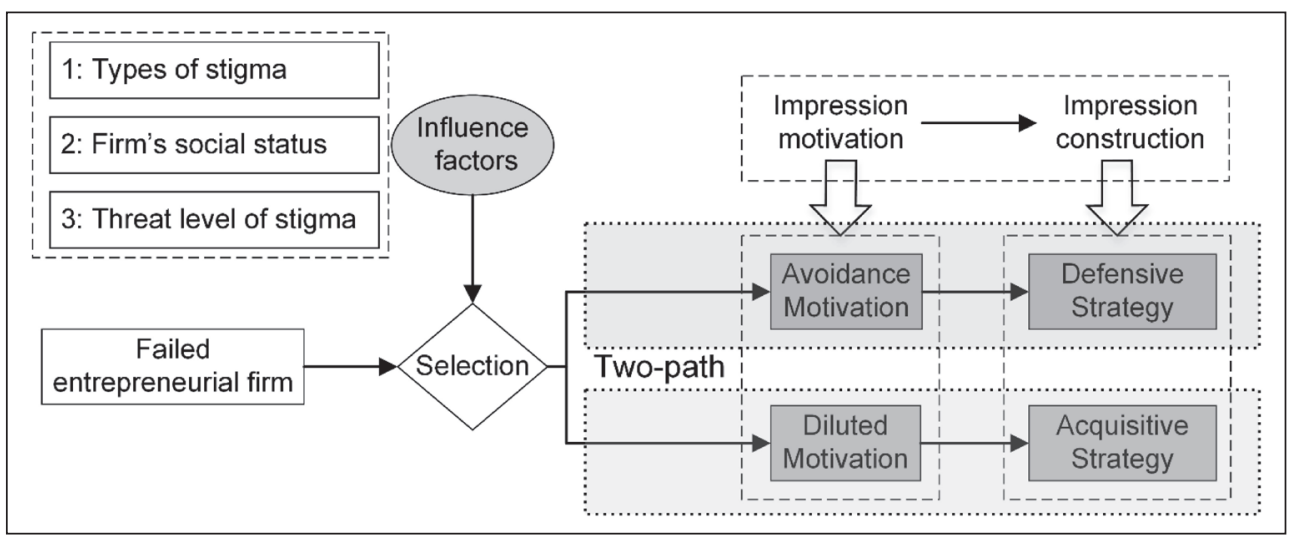

Source: own 
entrepreneurial failure stigma for the failed entrepreneurial firms.

Therefore, we posit the following:

Proposition 1: The types of entrepreneurial failure stigma affect the types of impression management strategy to cope with stigma. Specifically, in the face of justifiable stigma, the failed entrepreneurial firms form the avoidance motivation and then implement a defensive strategy of impression management. In the face of unjustifiable stigma, the failed entrepreneurial firms form the diluted motivation and then implement an acquisitive strategy of impression management.

Proposition 2: The social status of failed entrepreneurial firms affects the types of impression management strategies to cope with stigma. Specifically, to cope with the negative impact of entrepreneurial failure stigma, high social status firms adopt an acquisitive strategy of impression management, whereas low social status firms adopt a defensive strategy of impression management.

Proposition 3: The threat level of the entrepreneurial failure stigma affects the types of impression management strategy to cope with stigma. Specifically, as the threat level of entrepreneurial failure stigma increases, the dilution motivation of the failed entrepreneurial firms to stigma becomes stronger, and the firms are more likely to adopt the acquisitive strategy of impression management. If the threat level of entrepreneurial failure stigma is relatively low, then the avoidance motivation of the failure stigma is stronger, and the firms are more likely to adopt the defensive strategy of impression management.

\subsection{Application of the Theoretical Model}

Under the background of the entrepreneurial economy, the upsurge of innovation and entrepreneurship brings a wide reputation to the successful entrepreneurs, and the failure stigma also makes the failed entrepreneurial firms 'infamous'. How to cope with and repair entrepreneurial failure stigma, to promote the 'recovery' of the failed entrepreneurial firms, brings management challenges to the entrepreneurial firms and the society. The two-path theoretical model of impression management proposed in this study can help the failed entrepreneurial firms to treat the failure stigma positively and correctly and has important implications for the failed entrepreneurial firms to formulate the impression management strategy of failure stigma. Specifically, when the entrepreneurial firms suffer from stigma events, firms can form and judge the impression motivation of stigma management more rationally according to the types of stigma, the level of social status, and the threat level of stigma, to further choose different impression construction strategies according to the differences of impression motivation.

For example, when a firm is stimulated by a stigma event caused by a previous entrepreneurial failure, the firm can judge whether the failure stigma is a justifiable or unjustifiable stigma according to the public feedback on entrepreneurial failure stigma (Yang \& Guo, 2017). If the scope of stigma influence mainly focuses on the stakeholders of the failed entrepreneurial firms, forming the avoidance motivation of stigma response, to choose a defensive strategy in the implementation of the subsequent impression construction strategy (Cusin \& Passebois-Ducros, 2020), is more conducive to firms because the implementation objects of these impression management strategies are more connected with the firms. Or in the context of COVID-19, the public's attribution of entrepreneurial failure is also biased towards external factors that are highly uncertain. Therefore, in the choice of strategies to deal with the entrepreneurial failure stigma, the effect of defensive strategies of impression management such as shirking responsibility, defending and looking for scapegoats is more obvious.

In general, the application of the impression management strategy on entrepreneurial failure stigma should pay attention to the following aspects: First, the failed entrepreneurial firms should have a correct understanding of failure. In the face of failure, they can use the rhetoric of "catharsis" to persuade themselves, interpret failure as trial and error, show stakeholders that failure is a necessary experience for future success, and actively guide stakeholders' attitude toward their failure. Second, the failed entrepreneurial firms should keep a distance from the negative events that cause failure stigma, and they should try to explain that the cause of entrepreneurial failure is caused by external factors that are not controlled by them. This situation will not happen again in the 
follow-up entrepreneurial process. Particularly when failure is caused by the non-compliance of stakeholders, the firm should quickly define the responsible party and draw a clear line with it and refuse to be a scapegoat. Finally, the combined effect of defensive strategies of impression management is more evident. For example, concealing the truth may be immoral but is an effective temporary measure, which can gain time for other long-term effective strategies, such as shirking responsibility.

\section{Conclusions and Future Directions}

To explore how to use different types of impression management strategies to cope with failure stigma, this study established a two-path theoretical model of impression management strategy. The conclusions are as follows: according to the discrete process of impression construction determined by impression motivation, the stigma management strategy of failed entrepreneurial firms has two paths: 'avoidance motivation $\rightarrow$ defensive strategy of impression management' and 'diluted motivation $\rightarrow$ acquisitive strategy of impression management'. Moreover, in the selection mechanism of strategy, the formation of impression motivation is affected by the stigma type of entrepreneurial failure, the social status of the firm organization, and the degree of stigma threat.

A two-path theoretical model of the impression management strategy to cope with entrepreneurial failure stigma was proposed. This model and its future directions have the potential to expand the reach and impact of impression management to cope with entrepreneurial failure stigma. We can have the following ideas in the future direction:

First, from the perspective of impression management strategy, this study establishes a two-path theoretical model of coping with entrepreneurial failure stigma. Future research can be based on the conceptual framework of this theoretical model, combined with the methods of single-factor and scenario experiments, and design a proposal test to determine the types of impression management strategies of the failed entrepreneurial firms under different stimulus conditions.

Second, the future direction can focus on the consequences of impression management strategy implementation in the two-path theoretical model. According to relevant research, the outcome variable of impression management strategy often acts on the acquisition and maintenance of entrepreneurial firm legitimacy (Yu \& Chen, 2019; Soublière \& Gehman, 2020). Therefore, based on legitimacy theory, we further infer that the impression management strategies adopted by failed entrepreneurial firms to cope with failure stigma may have an impact on their entrepreneurial legitimacy. That is, the different combinations of defensive and acquisitive strategies in impression management may have a differential impact on entrepreneurial legitimacy.

Third, the future direction can consider the contingency effects of different cultural contexts in the application of the two-path theoretical model. Previous studies found that differences in an institutional environment, specifically the friendliness of fault-tolerance environment in innovation and entrepreneurship, affect the decision-making of entrepreneurs after failure. If fault-tolerant environments are friendlier, then entrepreneurs can more actively carry out follow-up entrepreneurial activities after failure. Therefore, combined with the twopath theoretical model proposed in this study, the future direction can examine the possible differences in the choice of impression management strategies to cope with failure stigma in different cultural contexts.

Acknowledgment: This study was supported by the Humanities and Social Sciences Research Project of the Ministry of Education of China (No. 20YJC630171), Natural Science Foundation of China (No. 72002206), and National Social Science Fund of China (No. 18CJLO06).

\section{References}

Amankwah-Amoah, J., Hinson, R. E., Honyenuga, B., \& Lu, Y. (2019). Accounting for the transitions after entrepreneurial business failure: An emerging market perspective. Structural Change and Economic Dynamics, 50, 148-158. https://doi.org/10.1016/j.strueco.2019.06.011

Bernardino, S., \& Freitas Santos, J. (2019). Network Structure of the Social Entrepreneur: An Analysis Based on Social Organization Features and Entrepreneurs' Demographic Characteristics and Organizational Status. Journal of Social Entrepreneurship, 10(3), 
346-366. https://doi.org/10.1080/19420676.20 18.1543725

Bolino, M., Long, D., \& Turnley, W. (2016). Impression Management in Organizations: Critical Questions, Answers, and Areas for Future Research. Annual Review of Organizational Psychology and Organizational Behavior, 3, 377-406. https://doi.org/10.1146/ annurev-orgpsych-041015-062337

Byrne, O., \& Shepherd, D.A. (2015). Different Strokes for Different Folks: Entrepreneurial Narratives of Emotion, Cognition, and Making Sense of Business Failure. Entrepreneurship Theory and Practice, 39(2), 375-405. https:// doi.org/10.1111/etap.12046

Cardon, M. S., Stevens, C. E., \& Potter, D. R. (2011). Misfortunes or mistakes?: Cultural sensemaking of entrepreneurial failure. Journal of Business Venturing, 26(1), 79-92. https://doi. org/10.1016/j.jbusvent.2009.06.004

Corrigan, P. W., Morris, S., Larson, J., Rafacz, J., Wassel, A., Michaels, P., Sandra Wilkniss, S., Batia, K., \& Rüsch, N. (2010). Self-stigma and coming out about one's mental illness. Journal of Community Psychology, 38(3), 259-275. https:// doi.org/10.1002/jcop.20363

Cusin, J., \& Passebois-Ducros, J. (2020). Impact of assertive and defensive impression management tactics on recruiter evaluation: The case of post-failure entrepreneurs in employment interviews. Canadian Journal of Administrative Sciences, 37(4), 396-410. https://doi.org/10.1002/cjas.1552

Durand, R., \& Vergne, J. P. (2015). Asset divestment as a response to media attacks in stigmatized industries. Strategic Management Journal, 36(8), 1205-1223. https://doi. org/10.1002/smj.2280

Hampel, C. E., \& Tracey, P. (2017). How Organizations Move from Stigma to Legitimacy: The Case of Cook's Travel Agency in Victorian Britain. Academy of Management Journal, 60(6), 2175-2207. https://doi.org/10.5465/amj.2015.0365

Kibler, E., Mandl, C., Farny, S., \& Salmivaara, V. (2021). Post-failure impression management: A typology of entrepreneurs' public narratives after business closure. Human Relations, 74(2), 286-318. https://doi. org/10.1177/0018726719899465

Kibler, E., Mandl, C., Kautonen, T., \& Berger, E. S. (2017). Attributes of legitimate venture failure impressions. Journal of Business Venturing, 32(2), 145-161. https:// doi.org/10.1016/j.jbusvent.2017.01.003
Lashley, K., \& Pollock, T. G. (2020). Waiting to Inhale: Reducing Stigma in the Medical Cannabis Industry. Administrative Science Quarterly, 65(2), 434-482. https://doi. org/10.1177/0001839219851501

Leary, M. R., \& Kowalski, R. M. (1990). Impression management: A literature review and two-component model. Psychological Bulletin, 107(1), 34-47. https://doi.org/10.1037/00332909.107.1.34

Li, J., Fang, M. Y., \& Sun, R. J. (2019). Research on the formation mechanisms of the stigma of entrepreneurial failure. Shanghai Management Science, 41(1), 60-65.

Lu, J., Ren, L., He, Y., Lin, W., \& Streimikis, J. (2019). Linking corporate social responsibility with reputation and brand of the firm. Amfiteatru Economic, 21(51), 442-460. https://doi. org/10.24818/EA/2019/51/442

Lu, J., Ren, L., Zhang, C., Liang, M., Stasiulis, N., \& Streimikis, J. (2020). Impacts of Feminist Ethics and Gender on the Implementation of CSR Initiatives. Filosofija. Sociologija, 31(1), 24-33. https://doi.org/10.6001/fil-soc.v31i1.4175

Martín-de Castro, G., Amores-Salvadó, J., Navas-López, J. E., \& Balarezo-Núñez, R. M. (2020). Corporate environmental reputation: Exploring its definitional landscape. Business Ethics: A European Review, 29(1), 130-142. https://doi.org/10.1111/beer.12250

McDonnell, M. H., \& King, B. (2013). Keeping up Appearances: Reputational Threat and Impression Management after Social Movement Boycotts. Administrative Science Quarterly, 58(3), 387-419. https://doi. org/10.1177/0001839213500032

Nagy, B. G., Pollack, J. M., Rutherford, M. W., \& Lohrke, F. T. (2012). The Influence of Entrepreneurs' Credentials and Impression Management Behaviors on Perceptions of New Venture Legitimacy. Entrepreneurship Theory and Practice, 36(5), 941-965. https://doi. org/10.1111/j.1540-6520.2012.00539.x

Pache, A. C., \& Santos, F. (2013). Inside the Hybrid Organization: Selective Coupling as a Response to Competing Institutional Logics. Academy of Management Journal, 56(4), 9721001. https://doi.org/10.5465/amj.2011.0405

Petkova, A. P., Rindova, V. P., \& Gupta, A. K. (2013). No News Is Bad News: Sensegiving Activities, Media Attention, and Venture Capital Funding of New Technology Organizations. Organization Science, 24(3), 865-888. https:// doi.org/10.1287/orsc. 1120.0759 
Schnackenberg, A. K., Bundy, J., Coen, C. A., \& Westphal, J. D. (2019). Capitalizing on Categories of Social Construction: A Review and Integration of Organizational Research on Symbolic Management Strategies. Academy of Management Annals, 13(2), 375-413. https:// doi.org/10.5465/annals.2017.0096

Shepherd, D. A., \& Haynie, J. M. (2011). Venture failure, stigma, and impression management: A self-verification, selfdetermination view. Strategic Entrepreneurship Journal, 5(2), 178-197. https://doi.org/10.1002/ sej.113

Shepherd, D. A., \& Patzelt, H. (2015). Harsh Evaluations of Entrepreneurs Who Fail: The Role of Sexual Orientation, Use of Environmentally Friendly Technologies, and Observers' Perspective Taking. Journal of Management Studies, 52(2), 253-284. https:// doi.org/10.1111/joms.12103

Simmons, S. A., Wiklund, J., \& Levie, J. (2014). Stigma and business failure: implications for entrepreneurs' career choices. Small Business Economics, 42(3), 485-505. https://doi.org/10.1007/s11187-013-9519-3

Simmons, S. A., Wiklund, J., Levie, J., Bradley, S. W., \& Sunny, S. A. (2019). Gender gaps and reentry into entrepreneurial ecosystems after business failure. Small Business Economics, 53(2), 517-531. https:// doi.org/10.1007/s11187-018-9998-3

Singh, S., Corner, P. D., \& Pavlovich, K. (2015). Failed, not finished: A narrative approach to understanding venture failure stigmatization. Journal of Business Venturing, 30(1), 150-166. https://doi.org/10.1016/j.jbusvent.2014.07.005

Smith, D., \& Rhiney, E. (2020). CSR commitments, perceptions of hypocrisy, and recovery. International Journal of Corporate Social Responsibility, 5, 1. https://doi. org/10.1186/s40991-019-0046-7

Soublière, J. F., \& Gehman, J. (2020). The Legitimacy Threshold Revisited: How Prior Successes and Failures Spill Over to Other Endeavors on Kickstarter. Academy of Management Journal, 63(2), 472-502. https:// doi.org/10.5465/amj.2017.1103

Stern, I., Dukerich, J. M., \& Zajac, E. (2014). Unmixed signals: How reputation and status affect alliance formation. Strategic Management Journal, 35(4), 512-531. https:// doi.org/10.1002/smj.2116

Sutton, R. I., \& Callahan, A. L. (1987). The Stigma of Bankruptcy: Spoiled Organizational
Image and Its Management. Academy of Management Journal, 30(3), 405-436. https:// doi.org/10.5465/256007

Triantafillidou, A., \& Yannas, P. (2020). Social media crisis communication in racially charged crises: Exploring the effects of social media and image restoration strategies. Computers in Human Behavior, 106, 106269. https://doi.org/10.1016/j.chb.2020.106269

Turnley, W. H., \& Bolino, M. C. (2001). Achieving desired images while avoiding undesired images: exploring the role of selfmonitoring in impression management. Journal of Applied Psychology, 86(2), 351-360. https:// doi.org/10.1037/0021-9010.86.2.351

Überbacher, F., Jacobs, C. D., \& Cornelissen, J. P. (2015). How Entrepreneurs Become Skilled Cultural Operators. Organization Studies, 36(7), 925-951. https:// doi.org/10.1177/0170840615575190

Ucbasaran, D., Shepherd, D. A., Lockett, A., \& Lyon, S. J. (2013). Life after Business Failure: The Process and Consequences of Business Failure for Entrepreneurs. Journal of Management, 39(1), 163-202. https://doi. org/10.1177/0149206312457823

Wang, S., Wang, L., Xu, Q., \& Zhu, Y. (2019). Rival absorptive capacity and innovation performance of an enterprise: The moderating effect of dual appropriability mechanisms. Transformations in Business \& Economics, 18(3C), 565-579.

Xiong, Y., Li, C. Q., \& Wei, Z. H. (2011). Media "sensational effect": Transmission mechanism, economic consequences and reputation punishment. Management World, 10, 125-140. https://doi.org/10.19744/j.cnki.111235/f.2011.10.011

Yang, J., \& Guo, L. H. (2017). Make statement or keep silent? A study on different behavior between state-owned company and private enterprises after negative reports. Nankai Business Review, 20(1), 83-95.

Yang, L., Liu, L., \& Wu, H. Z. (2010). Strategies of coping with stigma: A critical review. Advances in Psychological Science, 18(5), 819-830.

Yannopoulou, N., Koronis, E., \& Elliott, R. (2011). Media amplification of a brand crisis and its affect on brand trust. Journal of Marketing Management, 27(5-6), 530-546. https://doi.org /10.1080/0267257X.2010.498141

Yu, X. Y., \& Chen, Y. (2019). A literature review on impression management in 
entrepreneurship and future prospects. Chinese Journal of Management, 16(8), 1255-1264.

Zhang, B., Xu, L., \& Liu, Y. G. (2013). $A$ review and outlook of researches on organizational stigma. Foreign Economies and Management, 35(3), 64-72. https://doi. org/10.16538/j.cnki.fem.2013.03.009

Zhang, H., Amankwah-Amoah, J., \& Beaverstock, J. (2019). Toward a construct of dynamic capabilities malfunction: Insights from failed Chinese entrepreneurs. Journal of Business Research, 98, 415-429. https://doi. org/10.1016/j.jbusres.2018.06.020

Zhang, J., \& Luo, X. R. (2013). Dared to Care: Organizational Vulnerability, Institutional Logics, and MNCs' Social Responsiveness in Emerging Markets. Organization Science, 24(6), 1742-1764. https://doi.org/10.1287/ orsc. 1120.0813
Zhang, R., Wang, M. S., Toubiana, M., \& Greenwood, R. (2021). Stigma Beyond Levels: Advancing Research on Stigmatization. Academy of Management Annals, 15(1), 188222. https://doi.org/10.5465/annals.2019.0031

Zheng, X., Zhou, X. B., Chen, H. H., \& Yang, T. (2019). A comeback: What kind of national system design can promote reentrepreneurship from failure? Management World, 7, 136-151. https://doi.org/10.19744/j. cnki.11-1235/f.2019.0097

Zott, C., \& Huy, Q. N. (2007). How Entrepreneurs Use Symbolic Management to Acquire Resources. Administrative Science Quarterly, 52(1), 70-105. https://doi. org/10.2189/asqu.52.1.70 